\title{
MENINGKATKAN PRODUKTIVITAS TANAMAN PAKAN MELALUI SISTEM TANAM GANDA
}

\author{
Nyimas Popi I. ${ }^{1}$, Yuyun Yuwariah ${ }^{2}$, Ana Rochana ${ }^{1}$, Herryawan K.M. ${ }^{1}$, Mansyur $^{1}$ \\ ${ }^{1}$ Fakultas Peternakan Unpad, ${ }^{2}$ Fakultas Pertanian Unpad \\ Email : nyimaspopi@yahoo.co.id
}

\begin{abstract}
ABSTRAK
Lahan pertanian dan peternakan yang digunakan umumnya tidak bertambah bahkan cenderung menurun, oleh karena itu penggunaan lahan perlu dioptimalkan dengan cara salah satunya menanam sistem tanam ganda. Upaya pengelolaan lahan melalui sistem tanam ganda yang dilakukan adalah yang mendukung kesuburan lahan baik secara fisik, kimia dan biologi. Sistem tanam ganda memerlukan jenis tanaman yang sesuai dan lingkungan yang mendukung sehingga menghasilkan tanaman yang berkualitas tinggi dan ketersediaan tanaman pakan terpenuhi sepanjang tahun. Penerapan sistem tanam ganda mampu meningkatkan efisiensi penggunaan faktor lingkungan (cahaya matahari, air dan unsur hara), menghambat pertumbuhan gulma, menekan serangan hama dan penyakit, menghemat tenaga kerja dan meningkatkan pendapatan petani peternak.
\end{abstract}

Kata kunci: tanaman pakan, sistem tanam ganda, kesuburan lahan

\section{IMPROVEMENT PRODUCTIVITY OF FORAGE THROUGH MULTIPLE CROPPING SYSTEM}

\begin{abstract}
Agricultural and forage land used are generally not increased even tends to decrease, therefore the land use needs to be optimized; one of them is by mean of multiple cropping system. Land management efforts through the multiple cropping systems selected is supporting the fertility of soil physical, chemical and biological. Multiple cropping systems require an appropriate plant species and a supportive environment to produce high-quality crops and availability of feed crops are sufficient throughout the year. Application of Multiple cropping system can increase the efficiency of environmental factors (sun, water and nutrients), inhibits the growth of weeds, suppress pests and diseases, save labor and improve the income of livestock farmers.
\end{abstract}

Keywords: forage crops, multiple cropping systems, soil fertility

\section{PENDAHULUAN}

Ternak ruminansia untuk mencukupi kebutuhan hidup pokok, pertumbuhan produksi dan reproduksinya sangat membutuhkan pakan hijauan yang berkualitas tinggi dan tersedia sepanjang tahun. Jenis hijauan untuk ruminansia umumnya graminea, leguminosa dan ramban. Populasi ternak ruminansia yang terus menurun antara lain disebabkan karena tidak tersedianya pakan hijauan secara berkelanjutan. Pada masa sekarang dengan kepemilikan lahan yang terbatas, petani peternak menjual ternak untuk bercocok tanam. Kondisi yang dihadapi antara lain kesuburan lahan yang semakin berkurang, benih yang berkualitas rendah sehingga hasil panen menurun bahkan gagal panen, jatuhnya harga saat panen menyebabkan petani peternak mengalami kerugian besar dan untuk musim tanam selanjutnya terpaksa menjual ternaknya serta tidak sedikit dari petani peternak yang berhutang.

Pola tanam ganda dapat dijadikan solusi dalam pemenuhan kebutuhan pakan hijauan. Tanaman yang ditanam melalui sistem tanam ganda harus dipilih yang sesuai, mampu memanfaatkan ruang dan waktu secara efisien sehingga dalam persaingan mendapatkan cahaya matahari untuk fotosintesis, unsur hara dalam tanah, air dan ruang untuk tumbuh dapat dikendalikan bahkan bisa saling melengkapi untuk mendapatkan produksi dan kualitas yang tinggi. Penerapan sistem tanam ganda dapat meningkatkan efisiensi pemanfaatan lahan, konservasi tanah, air, dan menambah unsur hara, sehingga membantu keseimbangan kesuburan tanah yang terdiri dari kesuburan fisik, kimia dan biologi tanah. Pola tanam ganda merupakan bentuk usaha pengendalian gulma dan menekan perkembangan hama dan penyakit secara kultur teknis dan iklim mikro sehingga terjadi keseimbangan ekologis. 
Tanaman graminea termasuk tanaman golongan $\mathrm{C} 4$ menghendaki pencahayaan penuh dengan ciri habitus tinggi, tegak tidak bercabang dan kanopi yang renggang sehingga tanaman leguminosa yang tergolong tanaman $\mathrm{C}_{3}$ yang memiliki habitus pendek, tegak dan bercabang dengan kanopi yang rapat dapat tumbuh di bawahnya karena termasuk tanaman tahan naungan. Leguminosa memiliki peranan penting dalam meningkatkan tanaman pakan karena kemampuannya memfiksasi nitrogen di udara yang digunakan untuk nutrisi tanaman yang ditanam dengan sistem tanam ganda. Kedua tanaman ini sangat dianjurkan karena mampu meningkatkan hasil bobot kering dan nilai nutrisi tanaman pakan.

Pola tanam ganda terdiri dari tumpangsari dan tanaman berurutan dan terminologi (istilah) di luar klasifikasi yang telah dijelaskan yang terkait erat dengan tanam ganda adalah Sole cropping, monocropping, monocultur, crop rotation, cropping patern, cropping system, mixed farming, interculture dan alley cropping. Umumnya tanam ganda yang paling banyak dilaksanakan adalah tumpangsari (Yuwariah, 2011). Pengelolaan lahan dengan menanam tanaman pakan dalam sistem tanam ganda yang dilakukan dengan benar, mampu mencapai target peningkatan populasi ternak ruminansia dan pada akhirnya dapat meningkatkan pendapatan petani peternak.

\section{KESUBURAN LAHAN}

Tanaman sereal dan leguminosa yang ditanam dengan pola tanam ganda memiliki potensi untuk mengatasi penipisan hara tanah. Legum memainkan peran penting dalam fiksasi nitrogen yang diperlukan kedua tanaman dan menambah kesuburan tanah. Tumpangsari sereal dan biji-bijian tanaman legum membantu menjaga dan meningkatkan kesuburan tanah secara kimia dan biologi, karena tanaman leguminosa menyumbang 80-350 kg nitrogen (N) per hektar (Sanginga dan Woomer, 2009).

Upaya meningkatkan daya ikat tanah terhadap air pada musim kering, untuk meningkatkan produksi tanaman dapat dilakukan dengan memanfaatkan kapasitas sistem perakaran rumput yang relatif padat, sehingga bisa mengisi ruang pori tanah dengan kerapatan tinggi. Hal tersebut menyebabkan kesuburan tanah secara fisik menjadi lebih baik yang dicirikan dengan tanah menjadi gembur karena volume pori tanah tinggi dan kerapatan tanah rendah, sehingga tanah dapat menyimpan air (Prihar et. al., 2000). Rumput merupakan tanaman multiguna, selain berfungsi sebagai pakan, juga pencegah erosi karena rumput memiliki perakaran yang kuat, dapat tumbuh di tanah dengan tingkat kesuburan rendah dan tahan genangan air (Mira et al., 2015).

\section{FAKTOR LINGKUNGAN}

Pola tanam pada sistem tanam ganda sangat memungkinkan terjadinya kompetisi antar tanaman yang dibudidayakan terhadap unsur hara, air, cahaya dan ruang tumbuh. Kompetisi tersebut terjadi antara tanaman yang sejenis dan berbeda jenis tanaman. Kompetisi antara tanaman tersebut dapat dihindari dengan jarak tanam dan pemberian pupuk yang sesuai, air yang cukup dan sinar matahari yang dibutuhkan untuk fotosintesis (Sucipto, 2009). Intensitas sinar matahari yang rendah dalam tanam ganda pada leguminosa dalam barisan tanaman sereal yang rapat akan menurunkan suhu dan meningkatkan kelembaban relatih udara sehingga laju evapotranspirasi menjadi rendah. Suhu yang rendah sangat menguntungkan membukanya stomata sehingga penyerapan $\mathrm{CO}_{2}$ berjalan lancar dan dapat digunakan untuk proses fotosintesis. Tinggi dan lebar tajuk tanaman antara tanaman yang ditumpangsarikan akan berpengaruh terhadap cahaya matahari yang diterima yang selanjutnya berpengaruh terhadap produksi tanaman (Shesu, 1997).

Tumpangsari lebih efisien dalam penggunakan air dibandingkan tanaman tunggal, hal ini disebabkan naungan yang ditimbulkan tanaman sereal atau rumput dapat menahan air di dalam tanah sehingga dapat mengurangi penguapan (Gutlerrez, 2007). Penerapan penanaman beberapa jenis tanaman dalam sistem tanam ganda, dapat meningkatkan kemampuan tanah menyimpan air, menambah bahan organik dan unsur hara serta mencegah erosi permukaan tanah sehingga membantu keseimbangan biologis di dalam tanah (Atmojo, 2009).

\section{SISTEM TANAM GANDA}

Sistem tanam ganda meliputi tumpangsari atau disebut juga intercropping yang terdiri dari tanam campur (mixed intercropping : menanam dua atau lebih jenis tanaman tanpa pengaturan baris yang jelas), tumpangsari sistem baris (row intercropping : menanam dua atau lebih jenis tanaman secara serempak, dengan jarak tanam dan barisan yang teratur), tumpangsari sistem jalur (strip intercropping : menanam dua atau lebih jenis tanaman dengan masing-masing jenis tanaman ditanam secara berjalur dan berselingan, satu jalur terdiri dari satu jenis tanaman dalam beberapa baris, sehingga masingmasing jenis tanaman membentuk kelompok yang lebih luas), dan tanam sisip (relay intercropping : menanam dua atau lebih jenis tanaman dengan salah satu jenis tanaman ditanam diantara tanaman terdahulu, pada saat tanaman terdahulu berada dalam fase generatif yaitu berbunga atau mendekati waktu panen). Sistem 
tanam ganda selain tumpangsari yang lainnya adalah tanaman berurutan disebut juga sequential cropping yang terdiri dari double cropping (adalah suatu usaha penanaman pada sebidang lahan dengan dua kali panen habis selama periode setahun yang berasal dari dua kali penanaman, tripple cropping (adalah suatu usaha penanaman pada sebidang lahan dengan tiga kali panen habis selama periode setahun yang berasal dari tiga kali penanaman, quadrople cropping (adalah suatu usaha penanaman pada sebidang lahan dengan empat kali panen habis dalam setahun yang berasal dari empat kali penanaman, dan ratoon cropping (adalah mengusahakan tanaman kembali tumbuh dan menghasilkan melalui pucuk atau daun setelah tanaman tersebut dipanen. Umumnya tanam ganda yang paling banyak digunakan adalah pola tanam tumpangsari (Yuwariah, 2011).

Evaluasi produktivitas tanaman yang ditanam pada pola tumpangsari dinyatakan dengan nilai kesetaraan lahan (NKL), atau rasio setara tanah (RST) atau Land Equivalent Ratio (LER). Nilai Kesetaraan Lahan adalah luas relatif lahan pertanaman tunggal yang diperlukan untuk mendapatkan hasil yang sama dengan hasil yang diperoleh pada pola tanam tumpangsari, jika kedua tanaman tersebut memperoleh tingkat pengelolaan yang sama. Nilai kesetaraan lahan dinyatakan dalam bentuk rasio, jadi NKL adalah jumlah rasio atau perbandingan hasil tanaman tumpangsari terhadap hasil tanaman tunggalnya. Dalam menghitung NKL diperlukan data pembanding yang diperoleh dari tanaman tunggal. Perhitungan NKL hanya berlaku untuk tumpangsari dan pertanaman tunggal, maka NKL nya dianggap sama dengan satu. Perolehan NKL > 1, misalnya 1,30 berarti total produktivitas dalam tumpangsari 30\% lebih tinggi (Yuyun Yuwariah, 2011).

Imbangan pertanaman campuran (mixed intercropping) antara rumput afrika (Cynodon plectostachyus) dan kacang sentro (Centrosema pubescans) menunjukkan adanya produksi segar, produksi bobot kering, kandungan protein kasar dan kandungan kalsium hijauan. Imbangan 80\% rumput afrika 20\% kacang centro dapat mempertemukan antara kebutuhan kebutuhan hujauan dalam jumlah cukup banyak dan kualitas yang baik (Tidi Dhalika, 2006). Konsumsi nutrien terbaik diperoleh pada hijauan hasil tumpangsari arbila (Phaseolus lunatus) dan sorgum (Sorghum bicolor) pada jarak tanam arbila $120 \mathrm{~cm}$ dengan baris sorgum sejumlah 2 dan 3 diantara arbila (Koten et al., 2014).

Karakter morfo-fisiologi padi gogo yang memiliki karakter toleran kekeringan dengan daya hasil tinggi pada sistem tanam intercrops dengan rumput gajah ditunjukkan oleh varietas Kalimutu. Karakter morfofisiologi dalam tinggi tanaman dan luas daun yang tinggi, serta rendah akumulasi prolin namun mampu memberikan hasil tinggi pada kondisi kadar air tanah rendah ditunjukkan oleh varietas kalimutu (Ahadyat, et al., 2010).

Kedelai kultivar Pangrango yang memiliki sifat tahan naungan berpotensi untuk ditanam secara tumpangsari dengan jagung bahkan waktu penanamannya setelah jagung. Hasil kedelai tertinggi pada penelitian ini sebesar 3,33 ton $\mathrm{ha}^{-1}$ biji kering dihasilkan kultivar Wilis yang ditanam secara tumpangsari dengan jagung pada saat tanam bersamaan. Ada kecenderungan hasil jagung tertinggi berupa bobot biji kering dihasilkan pada sistem tumpangsari dengan kedelai kultivar Slamet yang waktu penanamannya tiga minggu lebih awal dari waktu penanaman kedelai. Secara umum kultivar kedelai yang paling menguntungkan pada penanaman tumpangsari dengan jagung adalah kultivar wilis, sedangkan waktu penanamannya adalah pada saat yang bersamaan. Kombinasi perlakuan ini menghasilkan nilai NKL (Nilai Kesetaraan Lahan) tertinggi 4,51 (Edhi Turmudi, 2002).

Pada tumpangsari sistem baris (row intercropping), dengan penambahan kerapatan tanaman kacang tanah pada jarak tanam tanaman jagung, ternyata tidak mengurangi kandungan kalsium dan fosfor tanaman jagung yaitu berturut-turut dari tumpangsari sistem baris 2:1 (dua baris tanaman jagung dan satu baris tanaman kacang tanah) menghasilkan kandungan kalsium $0,47 \%$ dan fosfor $0,14 \%$. Tumpangsari sistem baris 1:1 (satu baris tanaman jagung dan satu baris tanaman kacang tanah) menghasilkan kandungan kalsium $0,51 \%$ dan fosfor $0,14 \%$. Selanjutnya tumpangsari sistem baris 1:2 (satu baris tanaman jagung dan dua baris tanaman kacang tanah) mengandung kalsium 0,57\% dan 0,15\%. Selanjutnya pada tumpangsari sistem baris dengan penambahan kerapatan tanaman kacang tanah pada jarak tanam tanaman jagung juga tidak mengurangi kandungan kalsium dan fosfor tanaman kacang tanah yaitu mulai dari tumpangsari sistem baris 2:1 menghasilkan kandungan kalsium 1,76\% dan fosfor $0,17 \%$. dan pada tumpangsari sistem baris 1:1 menghasilkan kandungan kalsium $1,45 \%$ dan fosfor $0,16 \%$. Selanjutnya pada tumpangsari sistem baris 1:2 mengandung kalsium 1,65\% dan fosfor 0,18\% (Nyimas Popi et al., 2015). Nilai NKL pada tumpangsari 2:1 adalah 1,58 dan tumpangsari 1:1 bernilai 1,75 serta tumpangsari 1:2 memiliki nilai 2,12.

\section{Keuntungan Pola Tanam Ganda}

Keuntungan yang didapat dari sistem tanam ganda antara lain meningkatkan pertumbuhan, hasil dan kualitas tanaman yang disebabkan persaingan antar spesies berkurang jika dibandingkan persaingan dalam spesies. Tanaman yang ditanam pada sistem 
tanam ganda saling melengkapi dalam penggunaan sumber daya, menekan pertumbuhan gulma, hama dan penyakit. Keanekaragaman spesies tanaman dalam ekosistem pertanian dapat membatasi penyebaran hama, penyakit dan gulma. Meningkatkan kesuburan tanah. Konsevasi kesuburan tanah adalah bentuk rotasi yang dilakukan setiap musim. Bakteri rizobium mampu memiliki hubungan simbiosis dengan leguminosa dan dapat memfiksasi nitrogen diatmosfir menjadi nitrogen yang tersedia bagi tanaman leguminosa dan non leguminosa serta ditambahkan ke tanah (Mousavi dan Eskandari, 2011).

Dalam rangka meningkatkan kualitas hijauan pada sistem tanam ganda tidak hanya meningkatkan bobot kering tanaman tetapi juga peningkatan protein kasar dengan konsentrasi 19-23 g/ kg (Geren et al., 2008).

\section{SIMPULAN}

Peningkatan produksi pakan merupakan faktor kunci dalam perkembangan industri peternakan modern dalam menerapkan sistem tanam ganda yang menunjukkan potensi yang tinggi untuk meningkatkan produksi pangan berkualitas tinggi, pakan untuk ternak, bahan baku industri serta kelestarian lingkungan (seperti peningkatan kesuburan tanah, mengurangi prevalensi penyakit tanaman di lapangan).

\section{DAFTAR PUSTAKA}

Ahadiyat, Y. R. dan P. Hidayat. 2010. Kajian Morfologis dan Fisiologis pada 20 Galur Padi Gogo yang Berpotensi Toleran Kekeringan, Efisien Pemanfaatan P dan Daya Hasil Tinggi . Laporan Penelitian KKP3T Litbang Pertanian. Jakarta.

Atmojo, S. W., 2009. Pola Usaha Tani Konservasi. Fakultas Pertanian UNS. Solo.

Geren, H., R. Avioglo, H. Soya and B. Kir. 2008. Intercropping of corn with cowpea and bean: biomass yield and silage quality.Afr.J.Biotechnol. 7: 4100-4104.

Grutlerrez, M. F. A., J. S. Santiag, J. A. M. Molin., C. C. Nafate, M. Abud Archila, M. A. O. Llaven, R.rincon-Rosales
$\mathrm{R}$ and L.Dendooven. 2007. Vermicompost as a soil supplement to improve growth, yield and fruit quality of tomato (Lycopersicum esculentu). Bioresour Techno 198: 2781-2786.

Koten, B. B., R. Wea, R. Dsoetrisno, N. Ngadiono, B. Soewignyo. 2014. Konsumsi nutrien ternak kambing yang mendapatkan hijauan hasil tumpangsari arbila (Phaseolus lunatus) dengan sorgum sebagai tanaman sela pada jarak tanam arbila dan jumlah baris sorgum yang berbeda. J. Ilmu Ternak 1 (8) : 38-45.

Mira, D., K. Abubakar dan M. Yunus. 2015. Kajian potensi hijauan pakan pada lahan eksisting dan potensial untuk meningkatkan populasi ternak ruminansia di Kabupaten Aceh Besar.Agripet 15 (1) : 33-40.

Mousavi, S. R., H. Eskandari. 2011. A General overview on intercropping and its advantages in sustainable Agriculture. J. Appl. Environ.biol.Sci. 1(11):482-486.

Nyimas Popi I., Yuyun Yuwariah, Ana Rochana and Harun Djuned. 2015. Effect of intercropping between corn (Zea mays) and peanut (Arachis hypogaea) with arbuscular mycorrhizal fungi (AMF) on the yield and forage mineral content. Pak.J. Nutr. 14 (6): 362-365

Prihar, S., P. R. Gajri, D. K. Bembi, and V. K. Arora. 2000. Intensive cropping: Efficient use of water nutriens and tillage. Food Products.Press Inc. New York.London. Oxford.

Sanginga, N., and P. L. Woomer. 2009. Integrated soil fertility management in africa: Principles Practices and Development Process (eds). Tropical Soil Biology and Fertility Institute of the International Center for Tropical Agriculture.Nairobi.p.263.

Shesu, Y., W.S.Alhassan and C. J. C. Phillips. 1997. The effect of intercropping maize with Stylosanthes hamata at different raw spacing on grain and fodder yield and chemical composition. Tropical Grassland. 31 : 227-231.

Sucipto. 2009. Dampak pengaturan baris tanaman jagung (Zea mays L.) dan populasi kacang hijau (Phaseolus radiatus L.) dalam tumpangsari terhadap pertumbuhan dan hasil kacang hijau dan jagung. J. Agrovigor 2 (2): 67-78.

Tidi Dhalika, Mansyur, H. K. Mustafa dan H. Supratman. 2006. Imbangan rumput afrika (Cynodon plectostachyus) dan leguminosa sentro (Centrosema pubescans) dalam sistem pastura campuran terhadap produksi dan kualitas hijauan. J. Ilmu ternak. 6 (2):163-168

Turmudi, E. 2002. Kajian pertumbuhan dan hasil tanaman dalam sistem tumpangsari jagung dengan empat kultivar kedelai pada berbagai waktu tanam. JIPI. 4(2) : 89-96.

Yuwariah, Y. 2011. Dasar-Dasar Sistem Tanam Ganda. Jurusan Budidaya Pertanian. Fakultas Pertanian.Universitas Padjadjaran. Bandung. 